\title{
Pengembangan Desa Wisata Partisipatif-Mandatori: Studi Kasus pada Desa Belimbing, Pupuan, Tabanan-Bali
}

\author{
I Made Ardana Putra ${ }^{*}$, Made Suardani², I Nyoman Anom Purwa Winaya ${ }^{3}$, I Made \\ Rai Jaya Widanta4, I Wayan Dana Ardika5 \\ 1,2,3,4,5 Politeknik Negeri Bali, Indonesia \\ *Corresponding author:rai_widanta@yahoo.com
}

\begin{abstract}
Sektor pariwisata merupakan salah satu sektor perekonomian terbesar, hal ini dikarenakan semua sektor kehidupan seperti niaga, industri kecil rumahan, pertanian, pekebunan, perikanan dan lain sebagainya sangat bergantung pada perkembangan pariwisata. Namun dengan adanya pandmei covid-19, sektor pariwisata mulai merosot dan menyebabkan lumpuhnya kegiatan pariwisata. Berdasarkan masalah tersebut dapat dirumuskan tujuan penilitian yakni untuk mengembangkan desa wisata yang tepat guna ditengah wabah pandemi covid-19. Sehingga jenis penelitian yang digunakan adalah penelitian deskriptif dengan pendekatan kualitatif. Subjek dalam penelitian ini dibedakan menjadi dua, yakni kelompok peserta yang terlibat secara intensif dan peserta yang terlibat secara bermusim. Hal tersebut bergantung pada jenis kegiatan yang selenggarakan. Metode pengumpulan data digunakan adalah metode non tes dengan cara melakukan observasi, serta bertatap muka langsung dengan masyarakat. Data yang diperoleh kemudian dianalisis dengan teknik analisis deskriptif dengan menggabungkan antara teori yang ada dengan kondisi dilapangan. Adapun Hasil kajian dalam penelitian ini menunjukkan bahwa model partisipatif dan mandatori sangat membantu percepatan pengembangan desa wisata Belimbing ini. Partisipasi setiap unsur sangat bermanfaat membantu lancarnya pengembangan tersebut. Selain itu, regulasi yang mengatur rambu-rambu pengembangan desa wisata daerah Tabanan sangat membantu semua unsur pengembangan tersebut sehingga setiap unsur atau pihak yang terlibat memiliki pedoman pasti dalam pengembangan ini.
\end{abstract}

Keywords: Desa Wisata, Model Partisipatif-Mandatori, CBT

\section{Abstract}

The tourism sector is one of the largest economic sectors, this is because all sectors of life such as commerce, small home industry, agriculture, plantations, fisheries, and so on are very dependent on tourism development. However, with the covid19 pandemic, the tourism sector began to decline and caused tourism to be paralyzed. Based on this problem, research objectives can be formulated, namely to develop a tourist village that is appropriate during the Covid-19 pandemic outbreak. So that the type of research used is descriptive research with a qualitative approach. The subjects in this study were divided into two, namely groups of participants who were intensively involved and participants who were involved in the season. This depends on the type of activity that is carried out. The data collection method used is the non-test method by making observations and meeting face to face with the community. The data obtained were then analyzed using descriptive analysis techniques by combining existing theories with field conditions. The results in this study indicate that the participatory and mandatory models help accelerate the development of this Belimbing tourism village. The participation of each element is very useful in helping the development run smoothly. Also, the regulations governing the signs for the development of a tourism village in the Tabanan area are very helpful for all elements of this development so that every element or party involved has definite guidelines in this development.

Keywords: Tourism Village, Participatory-Mandatory Model, CBT

\section{Introduction}

Pariwisata merupakan barometer perekonomian masyarakat di Bali. Pariwisata di Bali berkembang sekitar empat dekade terakhir dan menjadi salah satu mata pencarian terbesar masyarakat, hal ini dikarenakan semua sektor kehidupan seperti niaga, industri kecil rumahan, pertanian, pekebunan, perikanan dan lain sebagainya sangat bergantung pada

$\begin{array}{lll}\text { History: } & & \text { Publisher: Undiksha Press } \\ \text { Received } & \text { : 02 August } 2020 & \text { Licensed: This work is licensed under } \\ \text { Revised } & : 09 \text { September } 2020 & \text { a Creative Commons Attribution 3.0 License } \\ \text { Accepted } & : 06 \text { October } 2020 & \text { : }\end{array}$


perkembangan pariwisata. Dalam perkembangan dunia pariwisata di Bali wisatawan menjadi stake holder terbesar dan berperan sebagai konsumen produk-produk lokal dengan hasil yang sangat menjanjikan, sehingga pemerintah provinsi Bali memfokuskan segala aspek perekonomian ke bidang pariwisata dan bergantung kepada hasil dari industri pariwisata (Raya \& Nugroho, 2019; Warami \& Dewi, 2015).

Munculnya pandemi covid-19 berdampak pada perubahan tatanan kehidupan masyarakat baik itu tatanan di bidang pendidikan, sosial budaya, maupun perkonomian (Chang et al., 2020; Wong et al., 2020). Pada bidang perekonomian adanya wabah virus covid-19 menyebabkan perekonomian di Indonesia lumpuh total dan berdampak langsung terhadap dunia pariwisata di Bali. Hampir sembilan puluh persen industri lainnya terkena dampak penuruan pariwisata ini ( Bellina and Citra 2020). Semua sektor yang bekaitan dengan pariwisata lesu. Karyawan yang bekerja di bidang pariwisata kehilangan pekerjaan mereka, seperti hotel, restoran, travel, jasa transportasi, laudry dan lain sebagainya. Dampaknya bahkan menjalar ke bidang lain seperti, pedagang, penyewaan rumah kos, penjual makanan, penjualan kendaraan, dan sebagainnya. Adanya kemerosotan industri pariwisata ini tidak dapat dibairkan terus menerus, karena jika dibiarkan akan berdampak terhadap meningkatnya jumlah pengangguran serta meingkatkan angka kemiskinan yang ada di provinsi Bali. Untuk mengatasi hal tersebut masyarakat mulai berupaya untuk mempertahankan kondisi perekonomian Bali yang lesu. Kebanyakan dari mereka beralih profesi dari pegawai atau pelaku pariwisata menjadi karyawan di bidang lain atau membuat usaha sendiri. Beberapa dari mereka tetap mengupayakan usaha di bidang pariwisata dengan memodifikasi pola-pola seerti produksi, pemasaran serta mencari konsumen yang memungkinkan. Salah satu upaya yang dilakukan masyarakat desa Belimbing adalah mengembangkan eko wisata.

Pengembangan eko wisata berbasis partisipasi-mandatori di Desa Belimbing, Pupuan, Tabanan-Bali dilakukan dengan menggunakan model CBT (community-based tourism). Dalam proses pengembangan desa wisata partisipasi masyarakat merupakan salah satu komponen penting, hal ini dikarenakan partisipasi masyarakat baik dalam bentuk dukungan mereka terhadap rencana dan program pengembangan ataupun penerimaan mereka terhadap putusan, perencanaan tersebut akan memengaruhi tingkat keberhasilan pengembangan tersebut selain itu adanya partisipasi masyarakat akan dapat membantu perkembangan pariwisata serta menumbuhkan kemandirian dalam proses pemberdayaan (Frasawi \& Citra, 2018; Istiyanti, 2020). Terdapat dua alasan mengapa partisipasi masyarakat sangat dibutuhkan dalam pengembangan pariwisata, yang pertama yakni untuk membantu pengambilan suatu keputusan terkait pengembangan pariwisata, dan yang kedua yakni untuk menentukan manfaat yang akan diterima oleh masyarakat dengan keberadaan industri tersebut (VGA et al., 2018).

Dalam pengembangan dunia wisata penggunaan program mandatori juga dapat membantu peningkatan kualitas. Program mandatori merupakan program wajib yang harus dikembangkan sesuai dengan regulasi yang dibuat oleh pemerintah. Dalam pengembangan program wisata desa ini, ada beberapa program mandatori atau program wajib yang dibuat dan ditetapkan oleh pemerintah kabupaten, kecamatan dan dilimpahkan ke pemerintahan desa. Istilah mandatori sering dilawankan dengan istilah voluntir atau sukarela, yaitu suatu yang dikerjakan karena semata-matau untuk berderma (Purwaningsih \& Mahagangga, 2018). Dengan kata lain, istilah yang pertama mengandung makna bahwa pengerjaan suatu kegiatan karena merupakan kewajiban pelaksana tersebut, dan istilah kedua mengandung makna pengerjaan suatu kegiatan karena pelaksana semata-mata ingin berderma atau melakukannya secara sukarela (Wardi et al., 2017). Sehingga pengembangan eko wisata berbasis partisipasimandatori merupakan suatu cara pengembangan desa wisata dengan mewajibkan masyarakat untuk berpartispasi secara aktif dan kreatif dalam setiap kegiatan. 
Pengembangan desa wisata yang hanya berbasis partisipasi-mandatori tidak akan cukup untuk mengembalikan kondisi perekonomian masyarakat setelah adanya pandemi covid-19 sehingga dirasa perlu penggunaan suatu metode pengembangan yang relevan dengan kondisi saat ini. Salah satu metode yang relevan digunakan dalam pengembangan desa wisata berbasis partisipasi-mandatori adalah model pengembangan CBT (communitybased tourism). CBT merupakan industri pariwisata yang menekankan konsep di mana masyarakat diberlakukan sebagai agen yang mampu mengelola dan mengembangkan objek wisata tersebut sehingga memberikan kesempatan atau access dalam manajemen dan pembangunan pariwisata yang berujung pada pemberdayaan politis melalui kehidupan yang lebih demokratis serta dalam hal pembagian defiden (Rahayu et al., 2016; Simanjuntak \& Sariffuddin, 2017). Ada tiga kriteria yang digariskan CBT: (1) masyarakat dilibatkan untuk mengontrol, mengatur, serta membangun wisata tersebut; (2) masyarakat yang tidak terlibat langsung dalam industri tersebut juga mendapatkan keuntungan; dan (3) adanya pemberdayaan secara politis dan demokratisasi serta pembagian keuntungan kepada komunitas yang kurang beruntung di desa tersebut. Adapun manfaat penggunaan model CBT dalam pengembangan desa yakni dapat membantu dalam mengupayakan adanya suatu perencanaan pendampigan yang membela masyarakat lokal serta serta memberikan kontrol sosial sehingga mampu mewujudkan kesejahtraan masyarakat (Nurhidayati, 2015). Hal tersebut dapat dilakukan dengan menciptakan proyek yang dapat menciptakan suatu pembangunan yang berkelanjutan dan menciptakan hubungan baik antara masyarakat lokal dengan pengunjung atau wisatawan dengan tetap memperhatikan faktor-faktor atau sistemsistem seperti infrastruktur, kesehatan, pendidikan, serta lingkungan (Hidayat, 2011; Marthalina, 2019)

Kajian tentang peranan desa wisata dalam menunjang perekonomian masyarakat lokal dilakukan oleh Leonandri \& Rosmadi (2018) kajian tersebut berhasil mengungkap bahwa beberapa problema yang dihadapi oleh masyarakat lokal, pemerintah daerah serta pengguna (stakekolders). Kajian kualitatif ini Pengembangan desa Palalangonyang, Bandung ini menganalisis kemampuan desa wisata yang dikembangkan untuk menyediakan lapangan kerja dan menyerap tenaga kerja, serta efek pembeangunan ekonomi masyarakat. Kajian ini menghasilkan bahwa peranan desa wisata. Kajian potensi desa sebagai basis pengembangan desa wisata juga dilakukan oleh (Latif, 2018), Hasil kajian ini menemukan bahwa ada tiga faktor pendukung community resilience, community resilience, yaitu (1) masyarakat atau individu tidak memiliki problema mendasar tentang rasa keunikan atau kepemilikan lahan atau gaya hidup, namun problema budaya yaitu sesuatu yang diterima dan dipelajari; (2) masyarakat lokal telah memiliki hubunan baik dengan pemerintah dan pemegang dan pembuat kebijakan; (3) community resilience bergantung pada fleksibilitas masyarakat. Selanjutnya kajian yang dilakukan oleh Attar et al., (2013) yang menunjukkan bahwa seluruh desa wisata di Kecamatan Bumiaji yang berbasis CBT memiliki potensi wisata dan obyek daya tarik wisata (ODTW) berupa atraksi alam, sumberdaya pertanian dan budaya yang dapat lebih dikembangkan. Penilaian potensi wisata dan obyek daya tarik wisata (ODTW) menunjukkan Desa Tulungrejo dan Desa Sumberbrantas termasuk klasifikasi Sangat Baik.

Berdasarkan jabaran mengenai pengembangan desa wisata berbasis partisipatifmandatori dengan menggunakan model CBT, dapat ditarik tujuan penelitian yakni untuk mengembangkan desa wisata, menjadi desa yang yang tepat guna. pengembangan desa wisata berbasis partisipatif-mandatori dengan menggunakan model CBT diharapkan dapat membantu pemerintah desa untuk meningatkan pendapatan desa serta dapat membuku lowongan pekerjaan bagi warga desa yang dirumahkan, sehingga sumber daya manusia di desa tersebut juga akan meningkat. 


\section{Materials and Methods}

Penelitian ini bertujuan untuk mengembangkan desa wisata Belimbing, Pupuan, Tabanan-Bali, sehingga dapat menjadi desa wisata yang yang tepat guna. Secara khusus, tujaun riset ini adalah untuk mengetahui pola pengembangan desa wisata Belimbing berbasis partisipatif mandatori. Pengembangan tersebut secara spesifik berfokus pada program wisata treking yang menyangkut beberapa aspek, seperti jalur treking, fasilitas penunjangnya, penyediaan program kuliner, serta pemberdayaan guide desa. Fokus penelitian pengembangan ini adalah treking Duren Taluh di desa Belimbing. Sehingga jenis penelitian yang digunakan adalah penelitian deskriptif dengan menggunakan pendekatan kualitatif. Subjek dalam penelitian dibedakan menjadi dua, yakni kelompok peserta yang terlibat secara intensif dan peserta yang terlibat secara bermusim. Hal tersebut bergantung pada jenis kegiatan yang selenggarakan. Peserta tersebut adalah kelompok PKK desa, kelompok karang taruna banjar dinas Duren Taluh, kelompok petani, kelompok sadar wisata desa, aparat desa, kelompok kuliner, serta masyarakat umum.

Metode pengumpulan data yang digunakan dalam penelitian kali ini yakni metode non tes dengan cara melakukan observasi, serta bertatap muka langsung dengan masyarakat guna berinterkasi dengan para partisipan yang terlibat di tempat penelitian selain itu pengumpulan data dalam penelitian ini juga dilakukan dengan model etnografis partisipatif di mana peneliti aktif bergabung dengan partisipan selama kegiatan riset utuk melakukan observasi dan wawancara (Widodo, 2016). Hal ini agar peneliti mampu memperoleh data yang seakurat dan selengkap mungkin. Data hasil riset dianalissi dengan memadukan atau membandingkan dengan teori-teori yang digunakan. Penyajian hasil riset dilakukan secara deskriptif dengan mendeskripsikan hasil perolehan data dilapangan, yakni data terkait dengan model partisipatif dan model mandatori dalam pengembangan desa wisata Belmbing tersebut. Hasil analisis riset kemudian disajikan dalam bentuk deskripsi menggunakan kalimatkalimat.

\section{Results and Discussion}

Pengembangan desa wisata Belimbing dengan model partisipatif merupakan pengembangan yang bersifat kolaboratif dengan melibatkan beberapa pihak. Ada beberapa pihak yang dilibatkan dalam pengembangan tersebut, seperti akademisi, pemerintah kabupaten dan kecamatan, desa adat dan desa dinas, masyarakat luas, petani, serta lembaga subak. Beberapa unsur baik dari desa maupun pemerintah dapat diilustrasikan pada gambar 1.

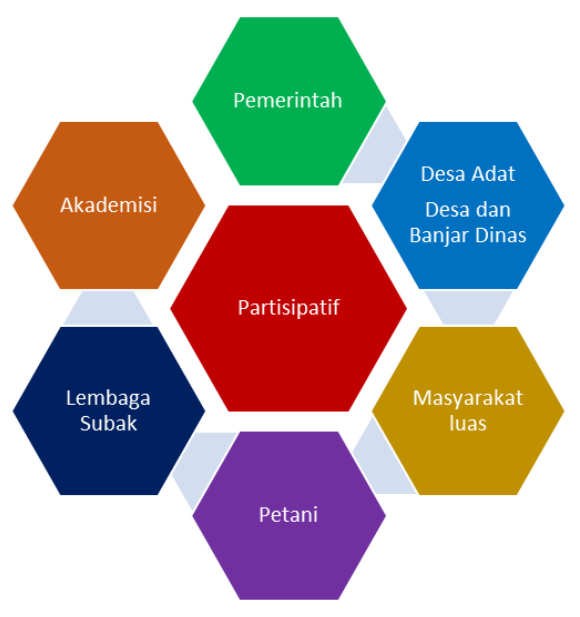

Gambar 1. Pihak yang dilibatkan dalam model partisipatif 
Akademisi berperan sebgai pionir hal ini dikarenakan akademisi berperan hampir di semua proses pengembangan tersebut, seperti planning, executing, controlling, evaluating, serta maintaining. Dalam implementasinya, akademisi mengawali program pengembangan tersebut dengan mengajukan dana kepada pihak pemberi dana dengan membuat proposal. Tahap planning telah dibuat serta disampaikan kepada pihak pemberi dana sebelum disampaikan kepada pihak-pihak lainnya. Setelah dana disetujui dan dicairkan, akademisi dengan jumlah tiga sampai lima orang menyampaikan planning tersebut kepada pihak lainnya yang terkait dengan desa wisata tersebut dan mengeksekusinya. Executing merupakan proses utama dan memakan waktu paling lama karena menyangkut pengadaan barang, pengembangan sistem, alat, tempat sumber daya manusia (SDM), serta mengimplementasikan program. Implementasi program memerlukan beberapa tindak lanjut agar keberhasilan program tersebut dalat dijamin. Oleh karena itu, ada tiga kegiatan penting yang mutlak dilakukan akademisi, yaitu mengontrol jalannya pelaksanaan program tersebut, mengevaluasi program tersebut, serta menjaga keberlangsungan program. Controlling tersebut merupakan suatu langkah pengaturan atau manajemen. Tanpa adanya manajemen yang baik, semua usaha atau bisnis akan terganggu. Evaluating juga memegang peranan penting karena perolehan hasil evaluasi akan membantu perusahaan atau industri bersangkutan dapat digunakan untuk menilai, membandingkan, merevisi, atau menetapkan usaha tersebut. Evaluasi dapat dilakukan dengan berbagai cara, seperti mengobservasi langsung, meminta responden untuk mengisi formulir atau angket, serta mengisi komentar. Hasil angket dan komentar tersebut dapat dijadikan bahan masukan untuk melakukan revisi program. Maintaining juga tidak kalah pentingnya karena aktivitas ini akan mampu minimal mempertahankan capaian yang telah diraih di samping juga untuk meningkatkan capaian tersebut dengan merevisi kelemahan-kelemahan yang telah ditemukan.

Pemerintah, pemerintah yang dimaksudkan adalah pemerintah Kabupaten Tabanan, Kecamatan Pupuan, Desa Belimbing yang memegang peranan penting dalam pengembangan desa wisata ini. Ada dua peranan pemerintah terkait dengan penetapan regulasi untuk pengembangan desa wisata Belimbing, peranan umum dan peran kusus. Secara umum, pemerintah berperanan penting dalam membuat kebijakan pengembangan desa wisata di seluruh Kabupaten Tabanan. Hasil dari renstra pengembangan atau rencana induk pengembangan (RIP) desa wisata di seluruh Tabanan menjadi pijakan bagi pengembangan di Desa Belimbing. Secara khusus, pemerintah kabupaten dan kecamatan melalui pemerintah Desa Belimbing menurunkan RIP tersebut ke dalam aturan yang lebih eksplisit yang mengatur eksistensi, penyelenggaraan, pembagian profit, pemberdayaan masyarakat, manajemen atau pengelolaan wisata serta penjagaannya. Selain itu secara kusus pemerintah berperan untuk membantu para akademisi untuk membuat kebijakan berupa peraturan desa (Perdes) Desa wisata Belimbing. Perdes ini akan dijadikan sebagai barometer tata cara pengelolaan dan pelaksanaan desa wisata. Dengan memiliki perdes desa wisata seperti ini, semua pihak yang terkait akan memiliki suatu rambu sehingga memudahkan untuk melangkah. Selain pemerintah Kabupaten Tabanan, pemerintah pusat juga merupakan salah satu unsur yang sangat memegang peranan dalam mensukseskan program tersebut. sebagai contoh, penetapan desa Belimbing sebagai Desa Belimbing juga merupakan salah satu desa dalam Kawasan Prioritas Pembangunan Nasional (KPPN) sejak tahun 2016 memberikan rambu-rambu terang terhadap pengembangan ini. Di samping itu, pengukuhan Desa Belimbing sebagai salah satu desa di kawasan NIKOSAKE (Nira, Kopi, Salak, Kelapa) khususnya desa penghasil nira, serta pengukuhan Desa Belimbing sebagai desa wisata dengan Surat Keputusan (SK) Bupati Tabanan Nomor 180/315/03/HK \& HAM/ 2018 merupakan sumbangsih pemerintah yang berharga.

Desa Adat dan Desa Dinas dan Banjar Dinas, Seperti diulas di depan, peran desa dinas sebagai perpanjangan tangan pemerintah kecamatan dan kabupaten sangat penting. 
Banjar dinas sebagai lembaga pemerintah terkecil pun memiliki peran yang sangat penting berkaitan dengan pembuatan regulasi. Selain itu, implementasi regulasi di masyarakat juga memerlukan kehadiran dan campurtangan banjar dinas karena lembaga tersebut bersentuhan langsung dengan masyarakat. Dalam pengembangan desa wisata ini, akademisi selalu berhubungan dengan desa dinas dan banjar dinas dalam beberapa hal, seperti pembuatan peraturan desa (Perdes), penggalian aspirasi masyarakat sebelum program pengembangan desa wisata dilaksanakan, peningkatan kapasitas masyarakat dalam hal peningkatan kesadaran masyarakat untuk hidup sehat dan mengelola sampah baik sampah organik maupun sampah non organik, mengajak masyarakat untuk melestarikan lingkungan dan lain sebagainya. Desa dan banjar dinas di desa Belmbing sering diikutkan dalam rapat baik di desa maupun ditingkat banjar, baik dalam rapat koordinasi tentang program pengembangan, rapat penggalian aspirasi masyarakat, rapat pengembangan banjar dinas, dan sebagainya. Dalam rapat koordinasi, sebagai contoh, banjar dinas sangat beperanan dalam menyampaikan informasi tentang pengembangan desa wisata, rencana detail pelaksanaan pengembangan, tahapan-tahapan pengembangan, pola manajemen, pemberdayaan SDM, perawatan dan upaya menjaga kelangsungan industri tersebut serta output pengembangan tersebut. Sosialisasi yang dilakukan per banjar dinas sangat efektif karena masyarakat masing-masing banjar dinas memiliki kesempatan luas untuk berdiskusi dengan baik. Upaya ini sangat efektif untuk memberikan pemahaman yang sama kepada masyarakat dari hulu ke hilir.

Masyarakat umum, peranan masyarakat umum dalam upaya pengembangan desa wisata ini juga tidak kalah pentingnya. Masyarakat luas yang tidak bersentuhan dengan industri wisata ini secara langsung juga akan mendapat keuntungan dengan adanya wisata desa yang berbasis community-based tourism (CBT). Seperti konsep CBT yang mampu merangkul semua lapisan masyarakat, pengembangan desa wisata ini juga melibatkan semua unsur masyarakat desa. Walaupun beberapa lapisan masyarakat tidak bersentuhan langsung dengan kegiatan wisata desa tersebut, namun ada pertimbangan dan asumsi-asumsi yang diperhatikan desa di masa mendatang. Pertimbangan dan asumsi tersebut adalah: (1) lapisan masyarakat tersebut akan menjadi pihak yang bisa menyumbangkan ide atau gagasan untuk mendukung dan memperbaiki program desa wisata; (2) karena mereka akan memperoleh imbas, seperti konsep yang ditawarkan oleh CBT, mereka akan menjadi peserta aktif di masa mendatang; (3) rasa nasionalisme mereka akan tumbuh jika ada pihak luar (akademisi) membantu mengembangkan desa mereka. Dengan pelibatan masyarakat umum di dalam beberapa kegiatan seperti rapat-rapat, menggali aspirasi mereka, melakukan surve persepsi masyarakat luas tentang eksistensi dan program pengembangan desa wisata Belimbing. Partisipasi masyarakat luas tersebut berhasil memberikan sumbangsih pemikiran inspiratif kepada pengembangang desa wisata tersebut. Masyarakat umum juga sangat berjasa untuk mendukung program pengembangan ini dalam hal mengorganisir dan menyediakan para peserta yang dilibatkan dalam program pengembangan SDM, seperti peserta pelatihan guide desa, peserta pelatihan kuliner, peserta pelatihan home industri lainnya penunjang program wisata desa Belimbing.

Petani, pelibatan petani dalam pengembangan ini sangat intensif. Petani yang dilibatkan adalah petani yang memiliki sawah yang dilalui jalur treking serta petani-petani yang sawahnya berada di luar atau jauh dari jalur treking yang dikembangkan. Petani-petani yang berkaitan secara langsung dengan jalue treking diajak secara lebih intensif untuk melakukan koordinasi. Koordinasi tersebut menyangkut beberapa hal, seperti memetakan jalur-jalur treking yang ada, mendata jenis-jenis jalur treking (jalan, jembatan, parit, dan lainlain), membahas model perbaikan-perbaikan yang perlu dilakukan pada setiap titik, membahas waktu pelaksanaan yang tepat untuk setiap titik, jangka waktu yang diperlukan serta teknik pelaksanaan perbaikan tersebut, serta periraan dana yang diperlukan untuk perbaikan tersebut. Sedangkan petani yang tidak memiliki sawah yang dilalui jalur tersebut 
juga dilibatkan dalam diskusi sejenis namun intensitasnya berkurang. Selain kegiatan koordinasi, para petani tersebut juga diundang untuk beberapa kegiatan penunjang, seperti: (1) pada saat pembukaan program yang melibatkan sebagian besar masyarakat Belimbing seperti karang taruna, kelompok sadar wisata, PKK, kelompok kuliner, dan petani; (2) pada saat pelatihan guide desa yang memandu tamu dan melintas sawah, telajakan atau perbatasan sawah mereka; (3) serta pada saat kegiatan gotong royong untuk memperbaiki jalur tersbut.

Lembaga Subak, lembaga subak tidak kalah pentingnya dalam membantu pembentukan program desa wisata ini. Keterlibatan organisasi di bidang agraris ini sangat diperlukan terutama dalam menyusun regulasi-regulasi untuk mengatur pengelolaan wisata desa. Seperti contoh, pada saat penyusunan perdes desa wisata Belimbing, pihak akademisi sangat bergantung dan tertolong dengan dilibatkannya organisasi subak. Beberapa klausul yang bersifat teknis dan implementatif sesuai dengan situasi dan kondisi di lapangan digagas oleh pihak subak. Kausul yang menyangkut kesejahteraan masyarakat khususnya petani telah sukses disusun berkat masukan-masukan dari organisasi subak. Seperti contoh, bagaimana keuntungan dari usaha desa wisata dapat dinikmati oleh petani, pihak-pihak di bawah banjar dinas yang seyogyanya memperoleh pembagian hasil penjualan program treking tersebut, serta besaran pembagian yang sepatutnya diterima oleh pihak-pihak tersebut. Selain itu, subak juga memberikan pendangan terkait dengan upaya perawatan serta kelangsungan hidup program wisata desa ini. Untuk itu, subak memberikan usulan agar disisikan dan dialokasikan dana perawatan berkala dengan menyisihkan pendapatan-pendapatan wisata desa tersebut.

Pengembangan program wisata desa yang bersifat mandatori memang lebih terbatas karena tren pengembangan desa wisata dewasa ini adalah community-based tourism (CBT). Namun tidak menutup kemungkinan bahwa peran serta pihak pemerintah sebagai penghasil dan pemegang kebijakan sangat dibutuhkan. Model mandatori merupakan model penugasan yang mewajibkan desa untuk mewujudkan visi-misi pemerintah pusat, pemerintah provinsi, pemerintah kabupaten, serta kecamatan. Hal ini memberikan rambu-rambu kepada desa Belimbing secara khusus tentang arah pembangunan di bidang pariwisatanya di masa mendatang dengan melibatkan semua komponen yang ada.

Beberapa produk hukum berupa peraturan-peraturan telah dihasilkan oleh pemerintah untuk mengatur dan menentukan rambu-rambu pembangunan kepariwisataan Tabanan, khususnya Desa Belimbing. Peraturan-peraturan yang menjadi referensi tersebut adalah: (1) peraturan pemerintah tentang Kawasan Prioritas Pembangunan Nasional (KPPN) dari pemerintah pusat; (2) perda NIKOSAKE (Nira, Kopi, Salak, Kelapa) yang mengatur kawasan-kawasan dengan penghasil produk-produk tersebut sesuai dengan Surat Keputusan (SK) Bupati Tabanan Nomor 180/315/03/HK \& HAM/ 2018; (3) Rancangan Peraturan Daerah (Raperda) Inisiatif DPRD Tabanan tentang Rencana Induk Pembangunan Kepariwisataan Kabupaten Tabanan tahun 2019-2027; (4) serta program Taman Teknologi Pertanian (TTP). Regulasi-regulasi ini mengatur pelaksanaan pengembangan desa wisata di seluruh kabupaten Tabanan.

Pengembangan bermodel mandatori ini sangat penting diupayakan karena beberapa alasan: (1) pengembangan wisata desa Belimbing tidak akan keluar dari jalur RIP dan visimisi pemerintah; (2) pengurusan ijin akan lebih mudah karena tidak berseberangan dengan rencana induk pemerintah; (3) pengkajian terhadap potensi-potensi pengembangan desa dapat dilakukan secara terpusat di tingkat pemerintah pusat atau daerah sehingga pihak desa tidak perlu mengadakan kajian awal. Regulasi-regulasi yang memandatkan pembangunan kepariwisataan di daerah Tabanan khususnya Desa Belimbing dapat dilihat pada gambar 2. 


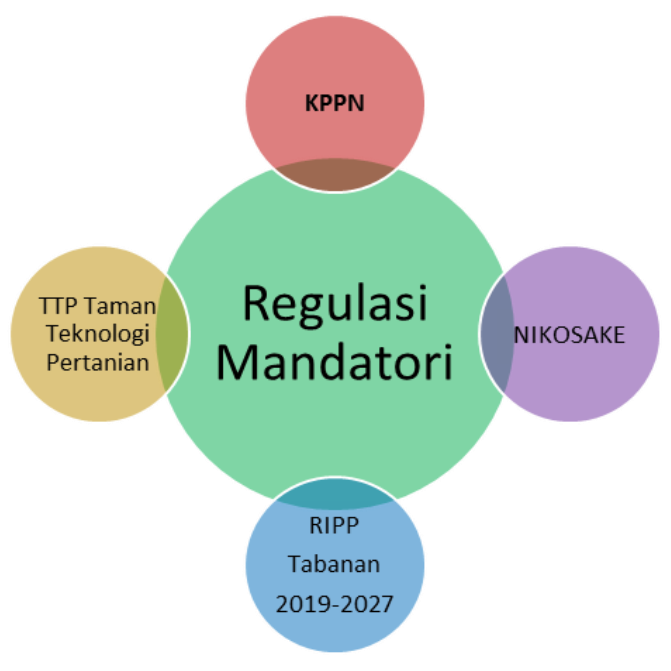

Gambar 2. Regulasi Mandatori

Pengembangan desa wisata berbasis partisipasi-mandatori di Desa Belimbing, Pupuan, Tabanan-Bali dilakukan dengan menggunakan model CBT diharapkan dapat menjadikan desa belimbing menjadi desa yang tepat guna, serta dapat membantu dalam meningkatkan pendapatan desa serta masyarakat. CBT merupakan industri pariwisata yang menekankan konsep di mana masyarakat diberlakukan sebagai agen yang mampu mengelola dan mengembangkan objek wisata tersebut sehingga memberikan kesempatan atau access dalam manajemen dan pembangunan pariwisata yang berujung pada pemberdayaan politis melalui kehidupan yang lebih demokratis serta dalam hal pembagian defiden (Rahayu et al., 2016; Simanjuntak \& Sariffuddin, 2017). Ada tiga kriteria yang digariskan CBT: (1) masyarakat dilibatkan untuk mengontrol, mengatur, serta membangun wisata tersebut; (2) masyarakat yang tidak terlibat langsung dalam industri tersebut juga mendapatkan keuntungan; dan (3) adanya pemberdayaan secara politis dan demokratisasi serta pembagian keuntungan kepada komunitas yang kurang beruntung di desa tersebut. Adapun manfaat penggunaan model CBT dalam pengembangan desa yakni dapat membantu dalam mengupayakan adanya suatu perencanaan pendampigan yang membela masyarakat lokal serta serta memberikan kontrol sosial sehingga mampu mewujudkan kesejahtraan masyarakat (Nurhidayati, 2015). Hal tersebut dapat dilakukan dengan menciptakan proyek yang dapat menciptakan suatu pembangunan yang berkelanjutan dan menciptakan hubungan baik antara masyarakat lokal dengan pengunjung atau wisatawan dengan tetap memperhatikan faktorfaktor atau sistem-sistem seperti infrastruktur, kesehatan, pendidikan, serta lingkungan (Hidayat, 2011; Marthalina, 2019)

Kajian tentang peranan desa wisata dalam menunjang perekonomian masyarakat lokal dilakukan oleh Leonandri \& Rosmadi (2018) kajian tersebut berhasil mengungkap bahwa beberapa problema yang dihadapi oleh masyarakat lokal, pemerintah daerah serta pengguna (stakekolders). Kajian kualitatif ini Pengembangan desa Palalangonyang, Bandung ini menganalisis kemampuan desa wisata yang dikembangkan untuk menyediakan lapangan kerja dan menyerap tenaga kerja, serta efek pembeangunan ekonomi masyarakat. Kajian ini menghasilkan bahwa peranan desa wisata. Kajian potensi desa sebagai basis pengembangan desa wisata juga dilakukan oleh (Latif, 2018), Hasil kajian ini menemukan bahwa ada tiga faktor pendukung community resilience, community resilience, yaitu (1) masyarakat atau individu tidak memiliki problema mendasar tentang rasa keunikan atau kepemilikan lahan atau gaya hidup, namun problema budaya yaitu sesuatu yang diterima dan dipelajari; (2) masyarakat lokal telah memiliki hubunan baik dengan pemerintah dan pemegang dan pembuat kebijakan; (3) community resilience bergantung pada fleksibilitas masyarakat. 
Selanjutnya kajian yang dilakukan oleh Attar et al., (2013) yang menunjukkan bahwa seluruh desa wisata di Kecamatan Bumiaji yang berbasis CBT memiliki potensi wisata dan obyek daya tarik wisata (ODTW) berupa atraksi alam, sumberdaya pertanian dan budaya yang dapat lebih dikembangkan. Penilaian potensi wisata dan obyek daya tarik wisata (ODTW) menunjukkan Desa Tulungrejo dan Desa Sumberbrantas termasuk klasifikasi Sangat Baik.

\section{Conclusion}

Pengembangan desa wisata Belimbing menganut model CBT dengan mengutamakan model partisipatif. Ada beberapa unsur yang dilibatkan secara partisipatif dalam pembangunan tersebut, seperti akademisi, pemerintah kabupaten dan kecamatan, desa adat dan desa dinas, masyarakat luas, petani, serta lembaga subak. Berbagai upaya dan kegiatan yang telah dilakukan oleh akademisi dan desa beserta unsur-unsur desa yang dilibatkan dalam pengembangan ini, seperti diskusi umum, rapat, surve, observasi, wawancara, FGD, uji coba, pelatihan dan lain sebagainya dalam upaya pengembangan desa Wisata Belimbing. Semua unsur telah berperan dan berpartisipasi aktif sesaui dengan tugas, tanggung jawab serta kapasitas mereka dalam memberikan saran, opini, respon pada pelaksanaan pengembangan ini.

Selain itu, melalui model mantori, peran pemerintah sangat mendukung pelaksanaan pengembangan ini. Peran pemerintah dalam membuat visi-misi, kebijakan, serta regulasi sangat membantu percepatan pengembangan desa wisata tersebut. Empat regulasi yang memberikan rambu-rambu pembangunan wisada desa Belimbing adalah (1) peraturan pemerintah tentang Kawasan Prioritas Pembangunan Nasional (KPPN) dari pemerintah pusat; (2) perda NIKOSAKE (Nira, Kopi, Salak, Kelapa) yang mengatur kawasan-kawasan dengan penghasil produk-produk tersebut sesuai dengan Surat Keputusan (SK) Bupati Tabanan Nomor 180/315/03/HK \& HAM/ 2018; (3) Rancangan Peraturan Daerah (Raperda) Inisiatif DPRD Tabanan tentang Rencana Induk Pembangunan Kepariwisataan Kabupaten Tabanan tahun 2019-2027; (4) serta program Taman Teknologi Pertanian (TTP). Regulasiregulasi ini mengatur pelaksanaan pengembangan desa wisata di seluruh kabupaten Tabanan.

\section{References}

Attar, M., Hakim, L., \& Yanuwiadi, B. (2013). Analisis potensi dan arahan strategi kebijakan pengembangan desa ekowisata di kecamatan bumiaji - kota batu. Journal of Indonesian Tourism and Development Studies, 1(2), 68-78.

Chang, T. Y., Hong, G., Paganelli, C., Phantumvanit, P., Chang, W. J., Shieh, Y. S., \& Hsu, M. L. (2020). Innovation of dental education during COVID-19 pandemic. Journal of Dental Sciences, 155. https://doi.org/10.1016/j.jds.2020.07.011

Frasawi, E. S., \& Citra, I. P. A. (2018). Partisipasi Masyarakat Dalam Pengembangan Desa Wisata Ambengan Kecamatan Sukasada. Jurnal Pendidikan Geografi Undiksha, 6(3), $175-185$.

Hidayat, M. (2011). Strategi Perencanaan Dan Pengembangan Objek Wisata (Studi Kasus Pantai Pangandaran Kabupaten Ciamis Jawa Barat). Tourism and Hospitality Essentials (THE) Journal, 1(1), 33-44.

Istiyanti, D. (2020). Pemberdayaan Masyarakat Melalui Pengembangan Desa Wisata di Desa Sukawening ( Community Empowerment Through Development of Tourist Villages in Sukawening Village ). Jurnal Pusat Inovasi Masyarakat, 2(1), 53-62.

Latif, A. N. K. (2018). Analysis of tourism villages development in Indonesia: case studies: three tourism villages. ASEAN Journal on Hospitality and Tourism, Vol 16.2, pp.99106. ASEAN Journal on Hospitality and Tourism, 16(2), 99-106. 
Leonandri, D., \& Rosmadi, M. L. N. (2018). The Role of Tourism Village to Increase Local Community Income. Budapest International Research and Critics Institute (BIRCIJournal): Humanities and Social Sciences, 1(4), 188-193. https://doi.org/10.33258/birci.v1i4.113

Marthalina. (2019). Pengembangan Kawasan Wisata Karst Rammang-Rammang di Kabupaten Maros. TRANSFORMASI: Jurnal Manajemen Pemerintahan, 11(2), 1741.

Nurhidayati, sri endah. (2015). Studi evaluasi penerapan Community Based Tourism ( CBT ) sebagai pendukung agrowisata berkelanjutan. Masyarakat, Kebudayaan Dan Politik Vol., 28(1), 1-10.

Purwaningsih, N. P. E., \& Mahagangga, I. G. A. O. (2018). Hambatan Desa Munggu Sebagai Desa Wisata Di Kabupaten Badung. Jurnal Destinasi Pariwisata, 5(2), 187-194.

Rahayu, S., Dewi, U., \& Fitriana, K. N. (2016). Strategi Pengembangan Community Based Tourism Sebagai. Jurnal Kajian Ilmu Administrasi Negara Volume, 4(2), 65-80. https://doi.org/https://doi.org/10.21831/jnp.v4i1.12615

Raya, S., \& Nugroho, S. (2019). Analisis Peran Stakeholder Desa Wisata Carangsari , Kecamatan Petang, Kabupaten Badung. Jurnal Destinasi Pariwisata, 7(2), 390-397.

Simanjuntak, F., \& Sariffuddin, S. (2017). Peran Local Champion Dalam Pengembangan Community Based Tourism (Cbt) Di Desa Wisata Candirejo, Magelang. Jurnal Pengembangan Kota, 5(2), 190-199. https://doi.org/10.14710/jpk.5.2.190-199

Sophie Bellina, Citra Tomy Tri Cahyaningrat, A. S. T. P. (2020). Dampak Karantina Wilayah Terhadap Perekonomian Indonesia. Jurnal IlmiahDunia Hukum, 5(1), 18-30.

VGA, N. A., Kusumawati, A., \& Hakim, L. (2018). Partisipasi Masyarakat Dalam Pengembangan Desa Wisata Serta Dampaknya Terhadap Perekonomian Warga Di Desa Tulungrejo Kota Batu. Jurnal Administrasi Bisnis (JAB), 61(3), 48-56.

Warami, H., \& Dewi, P. C. (2015). Wacana Apec : Legitimasi Dan Signifikasi Perekonomian Bali ( Kajian Wacana Kritis Parawisata ). Retorika: Jurnal Ilmu Bahasa, 1(1), 168184. https://doi.org/10.22225/jr.1.1.116.168-184

Wardi, Y., Abror, \& Trinanda, O. (2017). Wisata Islami Bagi Pelaku Wisata Di Kota Padang. International Journal of Community Service Learning, 1(3), 144-147. https://doi.org/http://dx.doi.org/10.23887/ijcsl.v1i3.12670

WIDODO, H. P. (2016). The Esp Vocabulary Portfolio As A Tool For Sustained Vocabulary Learning. Issues in Materials Development, 121-133.

Wong, G. L. H., Wong, V. W. S., Thompson, A., Jia, J., Hou, J., Lesmana, C. R. A., Susilo, A., Tanaka, Y., Chan, W. K., Gane, E., Ong-Go, A. K., Lim, S. G., Ahn, S. H., Yu, M. L., Piratvisuth, T., \& Chan, H. L. Y. (2020). Management of patients with liver derangement during the COVID-19 pandemic: an Asia-Pacific position statement. The Lancet Gastroenterology and Hepatology, 5(8), 776-787. https://doi.org/10.1016/S2468-1253(20)30190-4 